\title{
NEW INSIGHTS INTO BODY CONDITION SCORE AND ITS ASSOCIATION WITH FATTY LIVER IN HOLSTEIN DAIRY COWS
}

ŠAMANC $H^{*}$, KIROVSKI DANIJELA*, JOVANOVIĆ $M^{*}$, VUJANAC I*, BOJKOVIĆ-KOVAČEVIĆ SLAVICA**, JAKIĆ-DIMIĆ DOBRILA***, PRODANOVIĆ ${ }^{* * *}$ and STAJKOVIĆ SILVANA*

*University of Belgrade, Faculty of Veterinary Medicine, Serbia

** Veterinary station, Agriculture Cooperation Belgrade, Serbia

*** Scientific Veterinary Institute of Serbia, Belgrade, Serbia

(Received 15th May 2010)

The aim of this study was to estimate the association between body condition and fatty liver in high-yielding dairy cows. One hundred dry Holstein cows were selected. Cows were scored once for body condition during the dry period, puerperium and month 2 of lactation, according to the system provided by Elanco Animal Health Buletin Al 8478. Body condition loss was determined as marked if loss was over 0.7 points between two consecutive phases of cycles and over 1.5 points between puerperium and month 2 of lactation. Liver tissue samples were taken $12 d$ after calving and tested for lipid content. $50 \%$ of cows had mild (3.92 $\pm 3.33 \%$ fat), $33 \%$ moderate $(19.28 \pm 5.18 \%$ fat), and $17 \%$ severe fatty liver $(36.21 \pm 4.55 \%$ fat). The mean body condition scores were $3.79 \pm 0.55$ (dry period), $3.18 \pm 0.34$ (puerperium) and $2.90 \pm 0.29$ (month 2 of lactation). Marked body condition loss from the dry period to puerperium had $38 \%$ of cows, $20 \%$ from dry period to month 2 of lactation and $8 \%$ from puerperium to month 2 of lactation. Body condition scores out of the physiological range had $39 \%$ dry cows, $49 \%$ cows in puerperium and $9 \%$ cows at month 2 of lactation.

After dividing cows into groups according to fatty liver degree, it was shown that only cows with severe fatty liver were obese during the dry period and that $76.47 \%$ of cows from this group had marked condition loss from the dry period to puerperium, $47.06 \%$ from dry period to month 2 of lactation and $23.53 \%$ from puerperium to month 2 of lactation. These indicate that in cows with severe fatty liver lipomobilisation is intensive and starts around calving, before milk production enhacement.

Our results indicate a strong association between body condition and fatty liver in cows, which can be estimated only when body condition is analyzed in details. Besides, our results clearly indicate that body condition is not the only etiological factor that leads to fatty liver in dairy cows.

Key words: body condition score, fatty liver, Holstein cows 


\section{INTRODUCTION}

The onset of lactation is very stressful for high-yielding dairy cows, due to metabolic adaptations that are necessary to support increased milk production (Bauman and Currie, 1980). Since the postpartal period is characterized by negative energy balance (NEB), dairy cows mobilize large quantities of fatty acid from adipose tissue in order to meet energy demands (Hady et al., 1994; Markusfeld et al., 1997; Rukkwamsuk et al., 1999). If nutrients and mobilized fat energy meet the increased energy demands, milk production is maintained, cows are healthy but they lose in body weight during the first weeks of lactation (Rukkwamsuk et al., 1999). However, when energy demands for maintenance and milk production overcome the consumed energy and energy released by adipose tissue lipolysis, negative energy balance is profound and health disorders, especially fatty liver and ketosis, are usual (Gerloff, 2000). Ketosis is a metabolic disorder which develops when dairy cows have a good appetite, but dietary energy is not sufficient for generous lactation. Ketosis is characterized by stagnation in milk production and loss in body condition during early lactation (Duffield, 2000). Fatty liver is caused by increased and uncontrolled lipomobilisation that leads to accumulation of lipids in hepatocytes (Bobe et al., 2004). A greater proportion of cows with high milk production that have been overfed during the dry period and obese during peripartal period have fatty liver. Syndrome called "fat cow syndrome" was described by Morrow (1976) and Morow et al. (1979). It is well known that nutrition of high-yielding cows is primarily based on ad libitum intake of high-energy diets during early lactation. If this type of feeding is not restricted during late lactation and dry period the risk for appearance of obese cows in the population is high, especially if their service period is too long. Obese dry cows are more prone to metabolic disorders, especially fatty liver, during postpartal and early lactation period. Fatty liver is a disease with high incidence, since 30 to $60 \%$ of dairy cows in some populations have fatty liver in the first month after calving (Reid and Roberts, 1982; Bobe et al., 2004). However, obesity in dry cows does not always lead to fatty liver indicating that there are risk factors other than obesity that predispose the cow to development of fatty liver (Grummer, 1993; Drackly, 1999; Bobe et al., 2004; Šamanc et al., 2010).

Body condition score (BCS) is a valid indicator of energy status of dairy cows, especially during the transition period when tremendous changes in energy metabolism occur (Drackley, 1999; Roche et al., 2010; Bewley et al., 2008; Bewley et al., 2010). During the dry period body condition may be excessive, due to unrestricted feeding. Cows lose in body condition during early lactation due to NEB. As a result of NEB, cows have their lowest body condition score at approximately one to two months postpartum. Since BCS reflect energy balance during pregnancy and lactation, scientists strongly recommend scoring of cows as a useful and simple clinical indicator for evaluation of energy status in dairy cows (Roche et al., 2009; van Straten et al., 2009). Cows should be scored at least twice per year in order to avoid great oscillations in energy metabolism that may provoke fatty liver (Bobe et al., 2004; Grummer, 2008). Obesity does not 
necessarily cause fatty liver, especially when cows adapt their feed intake to their milk production (Smith et al., 1997). Regardless to that, body condition scoring should be used for balancing feed requirements for dairy cows during critical phases of productive-reproductive cycle in order to prevent metabolic disorders caused by uncontrolled lipomobilisation.

The aim of this study was to investigate the influence of body condition score determined at the dry period, puerperium and month 2 of lactation, as well as body condition loss during dry and early lactation period, on incidence and degree of fatty liver at early puerperium.

\section{MATERIAL AND METHODS}

One hundred dry cows that had yielded 7000 liters of milk or more per annum in the previous lactation were chosen from the commercial dairy herd and placed in the study. The cows ranged from 4 to 6 years of age. The cows were housed in a tie-stall barn. Ingredients and chemical compositions of the dry and early lactation cow diets are listed in Tables 1 and 2.

Body condition scoring (using five-point scale with quarter-point divisions) was performed on 100 pregnant Holstein dairy cows by the same investigator using the system provided by Elanco Animal Health Buletin Al 8478. BCS was determined by palpation and careful visual examination. Cows were scored once for body condition during the dry period (prepartum day $30 \pm 10$ ), puerperium (postpartum day $7 \pm 3$ ) and at month 2 ( \pm 5 days) of lactation. Results for BCS are presented as mean BCS and as digress from physiological values at examined periods. The physiological range of body condition scores for high-yielding Holstein cows is 3.25 to 4.00 (dry period), 3.25 to 3.75 (puerperium) and 2.50 to 3.25 (month 2 of lactation). Besides, body condition loss was determined as physiologically acceptable if loss was up to 0.7 between two consecutive phases of productive-reproductive cycles (dry period/puerperium and puerperium/month 2 of lactation) and up to 1.5 between puerperium and month 2 of lactation.

On day 12 after calving, liver percutaneous biopsies were obtained using a biopsy instrument following the method of Hojovcova and Kacafirek (1967). The biopsy was performed at the right 11 th intercostal space, approximately 15 to $20 \mathrm{~cm}$ below the horizontal line through the tuber coxae. A medium-sized cannula ( $\sim 6 \mathrm{~mm}$ o.d. and $\sim 4 \mathrm{~mm}$ i.d; $20.5 \mathrm{~cm}$ long) surrounding a solid, retractable needle-pointed trocar was inserted through the intercostals muscles and peritoneum into the liver in the direction toward the left shoulder. After boring the cannula into the liver, a sample ( 3 to $5 \mathrm{~cm}$ long and 3 to $4 \mathrm{~mm}$ in diameter) was obtained through creating a vacuum by drawing back the trocar and then flexing the tip of the cannula upward and gently pushing forward. The liver sample was expelled onto a clean wipe, blotted free of blood, and placed into storage vials that contained $10 \%$ buffered phormaldehyde solution for fixation. Liver tissue lipid content was determined. For pathohistological determination of lipids, sections were made using a freezing microtome and stained with Sudan III. Lipid content in the hepatocytes was determined through computer image analysis (Software Q Win). Cows were divided into three groups based on the degree of lipid 
accumulation in the liver: mild fatty liver ( $<10 \%$ fat), moderate fatty liver (10 to $30 \%$ fat), and severe fatty liver ( $>30 \%$ fat).

Table 1. Ingredients of cow's diets

\begin{tabular}{|c|c|c|}
\hline Ingredient (kg) & $\begin{array}{c}\text { During } \\
\text { dry period }\end{array}$ & $\begin{array}{c}\text { Until day } 100 \\
\text { of lactation }\end{array}$ \\
\hline Alfalfa hay & - & 3.43 \\
\hline Grass hay & 1.50 & - \\
\hline Wheat straw & 0.60 & - \\
\hline Corn silage $44 \%$ DM & - & 9.50 \\
\hline Corn silage $33 \% \mathrm{DM}$ & 10.0 & - \\
\hline Corn silage $33.94 \%$ DM & - & 9.00 \\
\hline Alfalfa haylage $51.79 \%$ DM & 2.50 & - \\
\hline Alfalfa haylage $47.40 \%$ DM & - & 5.00 \\
\hline Brewer's grain $21.00 \%$ DM & - & 5.00 \\
\hline Corn grain & 0.98 & 2.50 \\
\hline Barley grain & 0.50 & 1.50 \\
\hline Soybean grits & 0.30 & 1.30 \\
\hline Soybean meal $44 \% \mathrm{~N}$ & 1.10 & 1.13 \\
\hline Wheat flour & 0.50 & 1.30 \\
\hline Sugar beet pulp & - & 1.82 \\
\hline DextroFat SC & 0.10 & 0.40 \\
\hline Optigen II, 41\% N & - & 0.14 \\
\hline Dextrose monohydrate & 0.04 & 0.10 \\
\hline Dicalcium phosphate $18 \% \mathrm{P}$ & - & 0.27 \\
\hline Magnesium oxide & - & 0.05 \\
\hline Sodium bicarbonate & - & 0.15 \\
\hline Sodium chloride (iodized) & - & 0.07 \\
\hline Calcium carbonate & 0.04 & 0.03 \\
\hline Milkinal trocken 3\% & 0.08 & - \\
\hline Beta carotene & 0.004 & - \\
\hline TOTAL & 18.24 & 42.69 \\
\hline
\end{tabular}


Acta Veterinaria (Beograd), Vol. 60, No. 5-6, 525-540, 2010.

Samanc $\mathrm{H}$ et al.: New insights into body condition scor

and its association with fatty liver in Holstein dairy cows

Table 2. Chemical composition of cow's diets

\begin{tabular}{|c|c|c|}
\hline Chemical composition & $\begin{array}{l}\text { During } \\
\text { dry period }\end{array}$ & $\begin{array}{c}\text { Until day } 100 \\
\text { of lactation }\end{array}$ \\
\hline DM kg & 9.82 & 23.63 \\
\hline Net energy of lactation (NEL) MJ & 65.50 & 163.03 \\
\hline Crude protein (CP) \% & 15.03 & 16.05 \\
\hline Rumen undegradable protein (RUP) \% & 5.09 & 5.06 \\
\hline Crude fat \% & 3.82 & 4.78 \\
\hline Acid detergent fibre (ADF) \% & 25.31 & 22.08 \\
\hline Neutral detergent fibre (NDF) \% & 40.59 & 35.48 \\
\hline $\mathrm{Ca} \%$ & 0.64 & 0.90 \\
\hline $\mathrm{P} \%$ & 0.42 & 0.52 \\
\hline $\mathrm{Na} \%$ & 0.13 & 0.36 \\
\hline $\mathrm{Cl} \%$ & 0.17 & 0.29 \\
\hline $\operatorname{Mg} \%$ & 0.27 & 0.34 \\
\hline $\mathrm{K} \%$ & 1.30 & 1.18 \\
\hline $\mathrm{S} \%$ & 0.22 & 0.22 \\
\hline Mn ppm & 129.36 & 82.40 \\
\hline Cu ppm & 39.81 & 25.64 \\
\hline Zn ppm & 168.24 & 96.90 \\
\hline Co ppm & 1.03 & 0.54 \\
\hline $\mathrm{J} \mathrm{ppm}$ & 3.06 & 1.64 \\
\hline Fe ppm & 228.38 & 220.53 \\
\hline Se ppm & 1.14 & 0.70 \\
\hline Vit A IU/kg & 41234.28 & 21273.58 \\
\hline Vit D IU/kg & 4487.10 & 3445.30 \\
\hline Vit E IU/kg & 117.79 & 69.35 \\
\hline
\end{tabular}

\section{RESULTS}

Results of the content of lipids in the liver in cows $(n=100)$ showed that $50 \%$ of cows had mild fatty liver $(3.92 \pm 3.33 \%$ fat), $33 \%$ had moderate fatty liver (19.28 $\pm 5.18 \%$ fat), and $17 \%$ had severe fatty liver ( $36.21 \pm 4.55 \%$ fat).

The mean body condition scores of examined cows $(n=100)$ at dry period, puerperium and month 2 of lactation are presented at Table 3. 
Table 3. Body condition score in different phases of productive-reproductive cycles

\begin{tabular}{|c|c|c|c|}
\hline \multirow{2}{*}{} & \multicolumn{3}{|c|}{ Mean body condition score } \\
\cline { 2 - 4 } & Dry period & Puerperium & Mont 2 of lactation \\
\hline \hline $\mathrm{X}$ & $3.79 \pm 0.55$ & $3.18 \pm 0.34^{\star * \star}$ & $2.90 \pm 0.29 * \star \star$ aaa \\
\hline
\end{tabular}

$\star \star \star p<0.001$ compared to dry period; ${ }^{\text {aaa }} \mathrm{p}<0.001$ compared to puerperium

From table 3 it can be seen that average body condition scores at dry period and month 2 of lactation were within the physiological ranges, while the value at puerperium was slightly under recommended physiological values for this phase of productive-reproductive cycle. Besides, mean body condition scores at puerperium and month 2 of lactation were significantly lower than at dry period $(p<0.001$ respectively) and BCS at month 2 of lactation was significantly lower than at puerperium $(p<0.001)$.

Body condition losses were within physiological range: 0.61 points between dry period and puerperium; 0.28 points between puerperium and month 2 of lactation; 0.89 points between dry period and month 2 of lactation.

According to body condition loss, cows were divided into two groups: the moderate condition loss group and the marked condition loss group. Percents of cows with marked body condition loss (over 0.7 points between two consecutive phases of productive-reproductive cycles and over 1.5 points between puerperium and month 2 of lactation) are presented in Table 4.

Table 4. Percents of cows with marked body condition loss between different phases of productive reproductive cycle

\begin{tabular}{|l|c|}
\hline Dry period / puerperium & $38 \%$ \\
\hline Dry period / month 2 of lactation & $20 \%$ \\
\hline Puerperium / month 2 of lactation & $8 \%$ \\
\hline
\end{tabular}

Highest occurrence $(38 \%)$ of marked condition loss was determined between dry period and puerperium, while the lowest (8\%) was determined between puerperium and month 2 of lactation. These data suggests that marked condition loss has happened at the onset of lactation.

Distributions of individual body condition scores for all examined periods are shown in Figures 1, 2 and 3.

Analyses of Figures make a complete picture of body condition scores in the population, since Figures make a point on the direction of digression from physiological values ("shift to the left" refers to values that are lower than physiological; "shift to the right" refers to values that are higher than physiological). At dry period, $39 \%$ cows had BCS out of physiological range, in which $15 \%$ had lower and $24 \%$ higher values (obese cows) than recommended. During puerperium, $49 \%$ cows had BCS lower than physiologically accepted, while at month 2 of lactation only $9 \%$ of cows had BCS out of physiological range. 
Acta Veterinaria (Beograd), Vol. 60, No. 5-6, 525-540, 2010.

Samanc $\mathrm{H}$ et al.: New insights into body condition scor

and its association with fatty liver in Holstein dairy cows

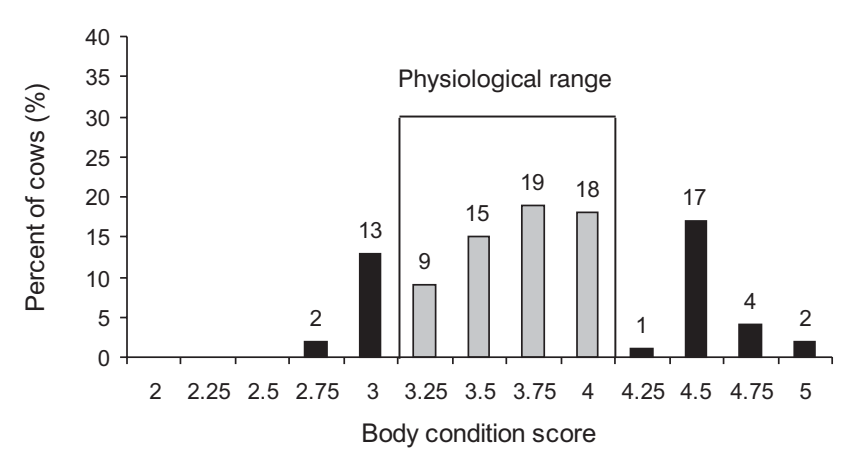

Figure 1. Distribution of individual body condition scores in cows at dry period

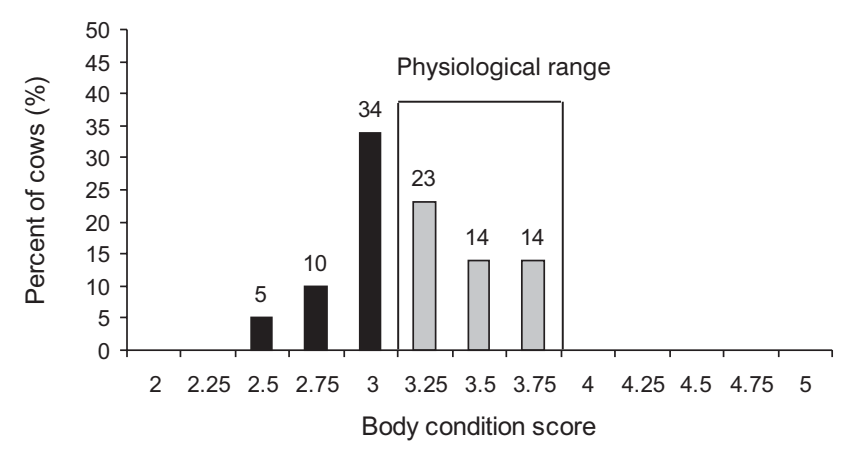

Figure 2. Distribution of individual body condition scores in cows at puerperium

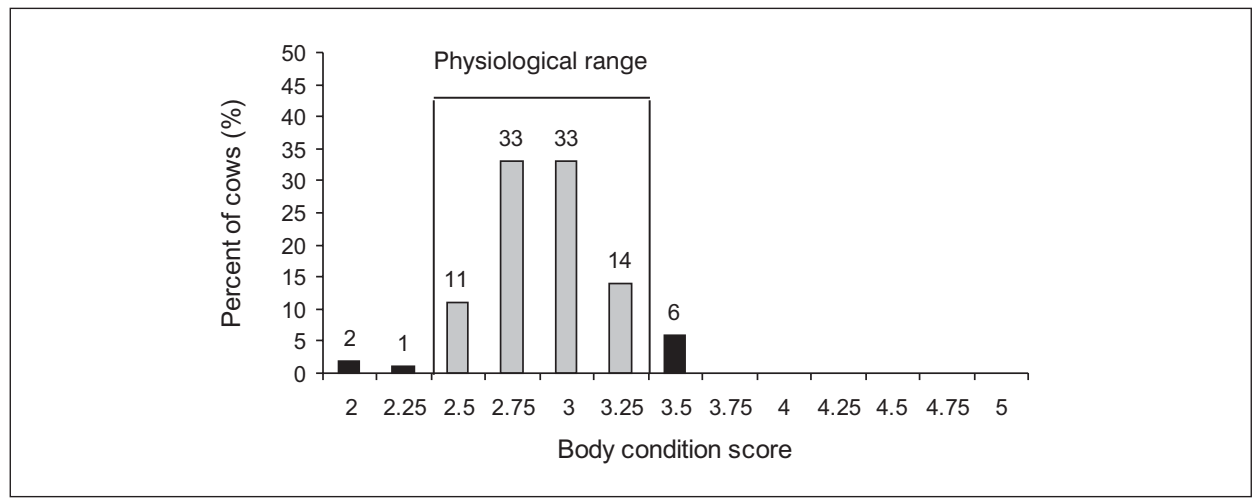

Figure 3. Distribution of individual body condition scores in cows at month 2 of lactation 
Data for BCS were grouped according to fatty liver degree in cows (mild, moderate and severe) in order to get a better picture about the relationship between BCS and fatty liver (Table 5).

Table 5. Body condition score in different phases of productive reproductive cycle for cows divided into groups according to fatty liver degree

\begin{tabular}{|l|c|c|c|}
\hline \multirow{2}{*}{ Fatty liver degree } & \multicolumn{3}{|c|}{ Mean body condition score } \\
\cline { 2 - 4 } & Dry period & Puerperium & Mont 2 of lactation \\
\hline \hline Mild $(\mathrm{n}=50)$ & $3.56 \pm 0.55$ & $3.06 \pm 0.31$ & $2.86 \pm 0.27$ \\
\hline Moderate $(\mathrm{n}=33)$ & $3.91 \pm 0.43^{\star *}$ & $3.26 \pm 0.33^{* *}$ & $2.96 \pm 0.33$ \\
\hline Severe $(\mathrm{n}=17)$ & $4.23 \pm 0.46^{* * * a}$ & $3.38 \pm 0.31^{* * *}$ & $2.95 \pm 0.28$ \\
\hline
\end{tabular}

${ }^{* *} p<0.01$ compared to mild fatty liver; ${ }^{* *} p<0.001$ compared to mild fatty liver;

$a_{p}<0.001$ compared to moderate fatty liver

Only dry cows with severe fatty liver had BCS higher than physiological values, meaning that they were obese (Table 5). Body condition losses were, as expected, highest in cows with severe fatty liver: 0.85 (dry period/puerperium), 1.28 (dry period/month 2 of lactation) and 0.43 (puerperium/month 2 of lactation).

The percents of cows that had marked condition loss within groups with different fatty liver degree are shown in Table 6.

Table 6. Percents of cows with marked body condition loss between different phases of productive reproductive cycle

\begin{tabular}{|l|c|c|c|}
\hline Fatty liver degree & $\begin{array}{c}\text { Dry period / } \\
\text { puerperium }\end{array}$ & $\begin{array}{c}\text { Dry period / } \\
\text { month 2 of lactation }\end{array}$ & $\begin{array}{c}\text { Puerperium / } \\
\text { month 2 of lactation }\end{array}$ \\
\hline \hline Mild $(\mathrm{n}=50)$ & 18 & 16 & 4 \\
\hline Moderate $(\mathrm{n}=33)$ & 48.49 & 12.12 & 6.07 \\
\hline Severe $(\mathrm{n}=17)$ & 76.47 & 47.06 & 23.53 \\
\hline
\end{tabular}

Marked losses in body condition were more often in cows with severe fatty liver than in cows with moderate and mild fatty liver. Additionally, in most cases marked changes in body condition were detected between the dry period and puerperium cows with moderate and mild fatty liver showed a similar trend.

Distributions of individual body condition scores for cows with different fatty liver degree and at different stages of productive reproductive cycles are presented in Figures 4 to 12.

It can be seen from Figures 4,5 and 6 that $12 \%$ of dry cows with mild, $21.21 \%$ dry cows with moderate and $67.72 \%$ dry cows with severe fatty liver had body condition higher than physiologically recommended ("shift to the right").

"Shift of body condition to the left" was detected in $62 \%$ of puerperal cows with mild, $45.45 \%$ of cows with moderate and $17.64 \%$ of cows with severe fatty liver (Figures 7, 8 and 9). 
Acta Veterinaria (Beograd), Vol. 60, No. 5-6, 525-540, 2010.

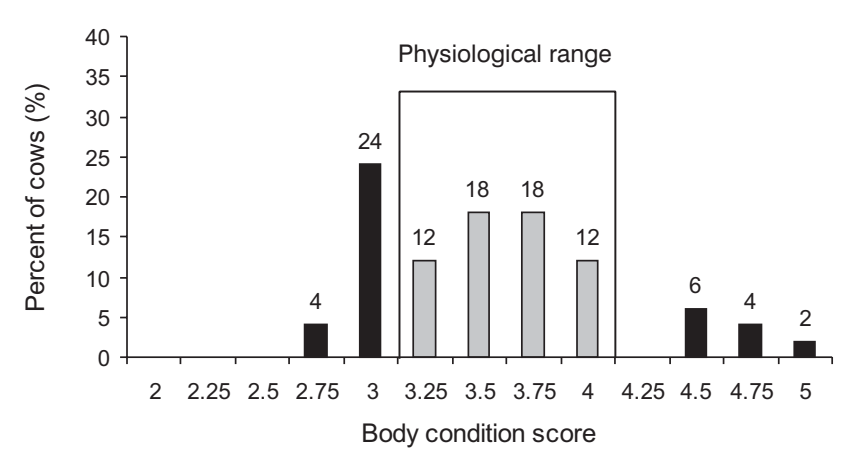

Figure 4. Distribution of individual body condition scores at dry period in cows with mild fatty liver

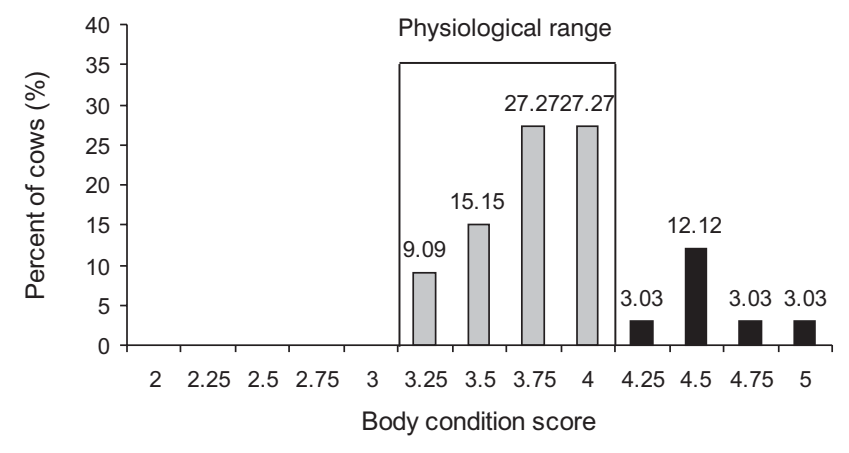

Figure 5. Distribution of individual body condition scores at dry period in cows with moderate fatty liver

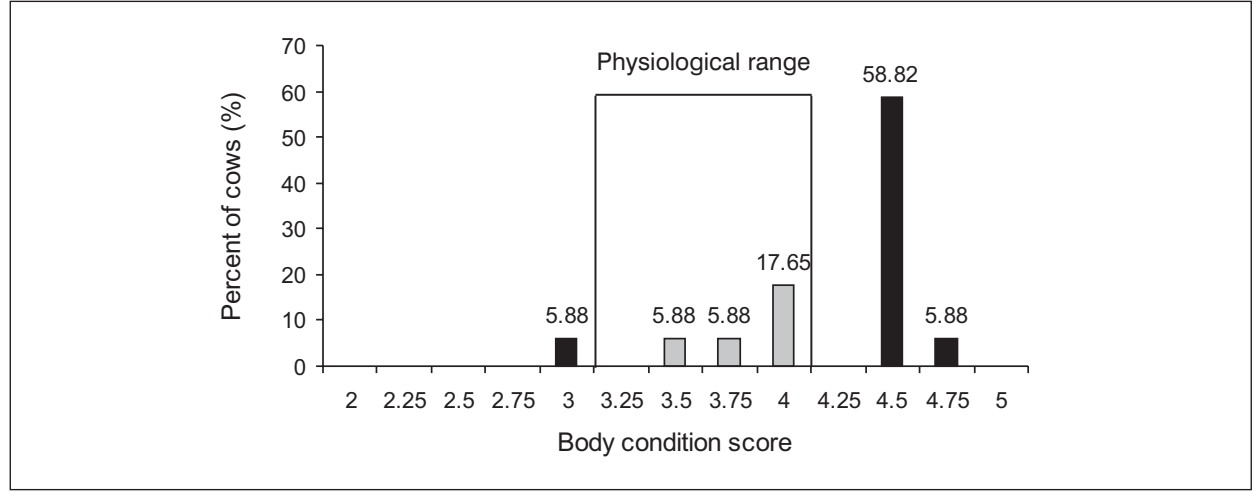

Figure 6. Distribution of individual body condition scores at dry period in cows with severe fatty liver 


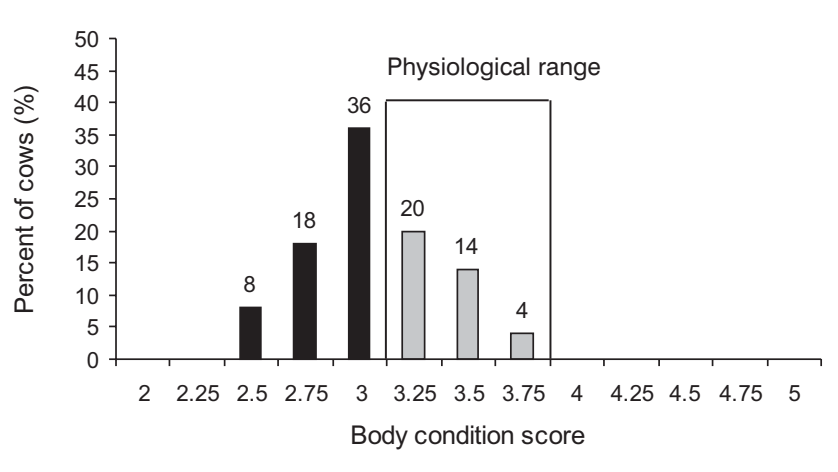

Figure 7. Distribution of individual body condition scores at puerperium in cows with mild fatty liver

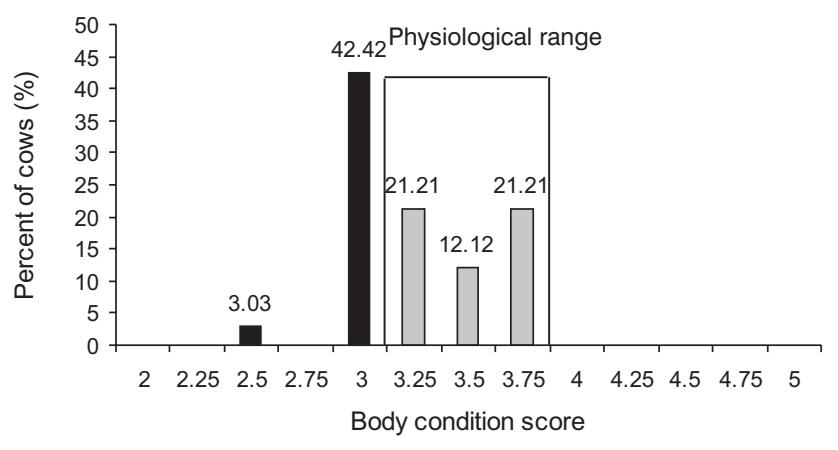

Figure 8. Distribution of individual body condition scores at puerperium in cows with moderate fatty liver

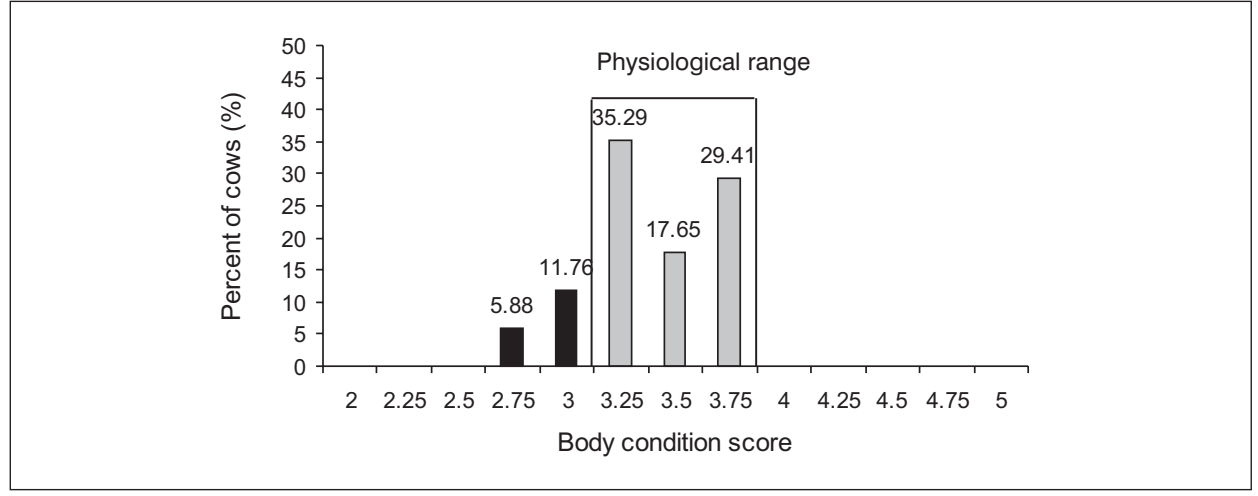

Figure 9. Distribution of individual body condition scores at puerperium in cows with severe fatty liver 
Acta Veterinaria (Beograd), Vol. 60, No. 5-6, 525-540, 2010.

Samanc $\mathrm{H}$ et al.: New insights into body condition scor

and its association with fatty liver in Holstein dairy cows

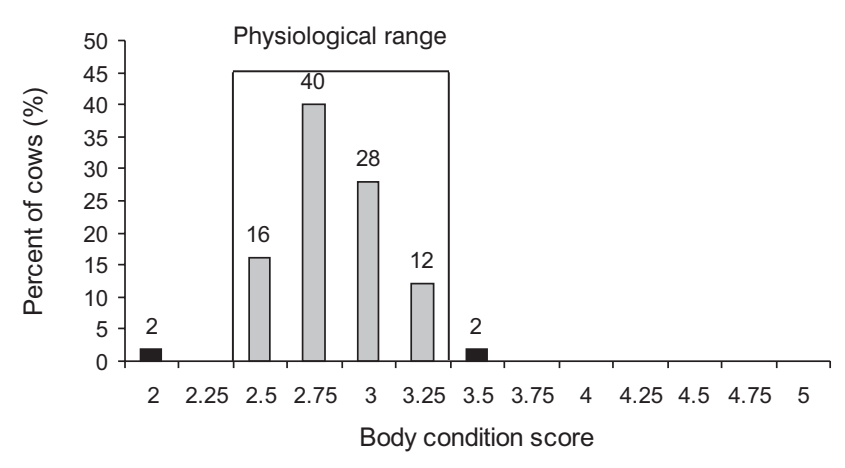

Figure 10. Distribution of individual body condition scores at month 2 of lactation in cows with mild fatty liver

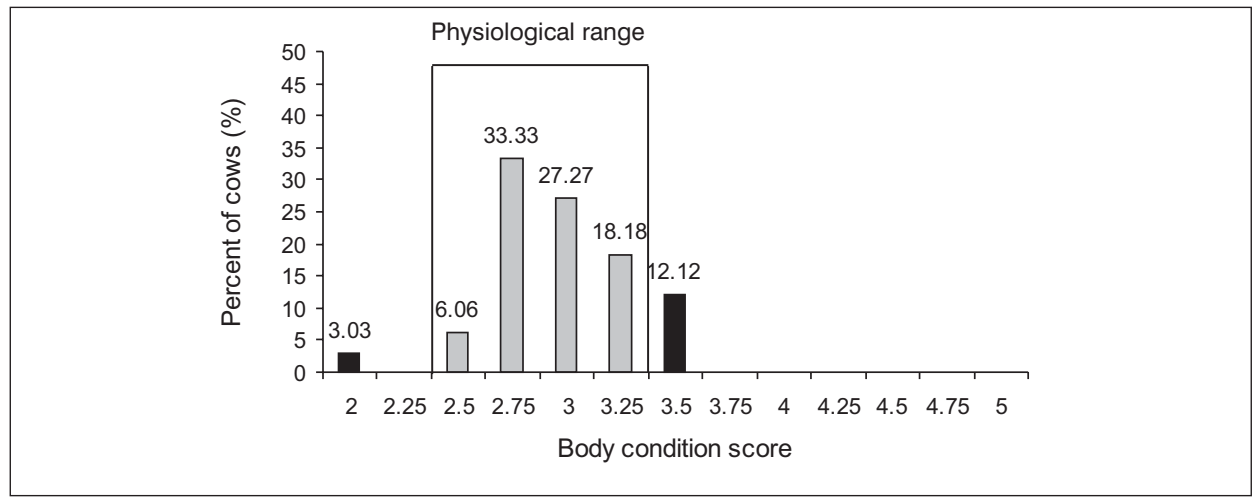

Figure 11. Distribution of individual body condition scores at month 2 of lactation in cows with moderate fatty liver

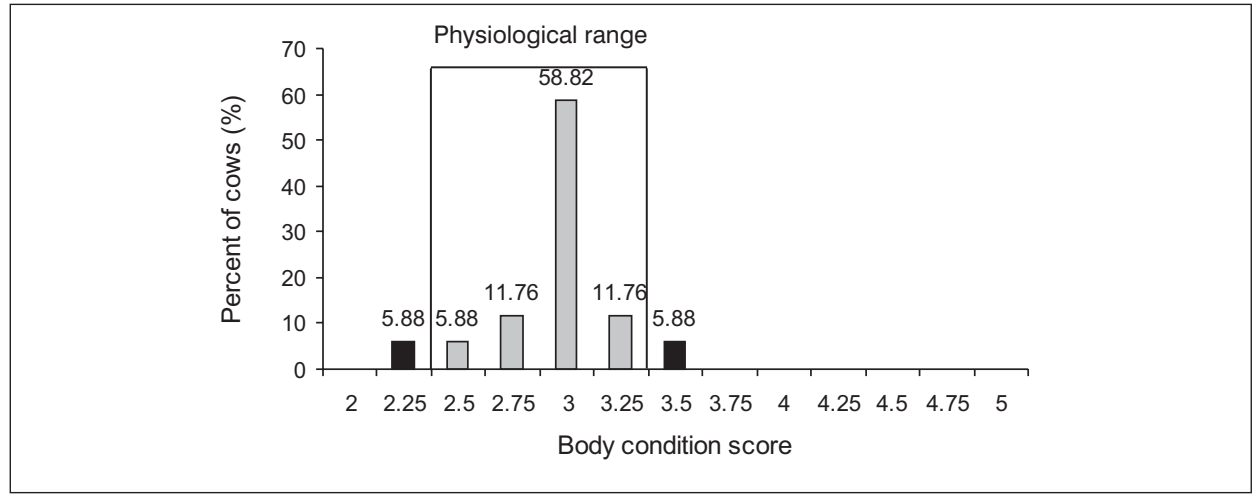

Figure 12. Distribution of individual body condition scores at month 2 of lactation in cows with severe fatty liver 
Finally, distributions of individual body condition scores at month 2 of lactation were similar in all three groups of cows (Figures 10, 11 and 12) with a note that the percent of cows with body conditions that were out of the physiological range was lowest in the group of cows with mild fatty liver.

\section{DISCUSSION}

Fatty liver is one of the major metabolic disorders in Holstein cows (Katoh, 2002; Jorristma, 2003; Bobe et al., 2004) with high incidence in populations (Gall, 2007; Šamanc et al., 2008). Investigations performed in Holstein cows in European Union and the United States showed that moderate fatty liver appears more often than severe fatty liver (Reid, 1980; Gröhn et al., 1987; Mazur et al., 1988; Acorda et al., 1995; Jorristma et al., 2001; Gerloff et al., 1986; Herdt, 1991). Our previous work showed that incidence of fatty liver on two dairy farms in Serbia was $18.33 \%$ and $43.32 \%$, respectively (Šamanc et al., 2008). At farm with higher incidence of fatty liver, marked digresses of body conditions from physiological values were detected in late lactation and dry cows. It is well known that obese dry cows have a greater decrease in feed intake around calving, and therefore, have a pronounced negative energy balance which leads to severe fatty liver (Morrow, 1976; Jorristma, 2003; Stockdale, 2001). Namely, in obese cows (BCS>4), lipolysis of adipose tissue is more intensive than in the cows with normal BCS (Rukkwamsuk et al., 1998). Our results showed significant difference between body conditions at dry period and puerperium, puerperium and month 2 of lactation and dry period and month 2 of lactation (Table 3). These findings are in accordance with the change in energy balance during the transition period which continue until month 2 of lactation i.e. until energy balance is established again. Namely, onset of lactation is characterized by negative energy balance which is followed by marked body condition loss (Jorristama et al., 2003; Rukkwamsuk et al., 1999).

However, some authors indicate that obesity does not necesserally cause fatty liver, especially when cows adapt their feed intake to their milk production (Smith et al., 1997). Even more, it is an open question if fatty liver can occure in cows with body condition score lower than 2.5 points around calving, since those cows have not stored excesive lipids in the body (Bobe et al., 2004). It is not unusual that average body condition scores are within the physiological range, but health problems in cows indicate disturbance in energy metabolism. That was the case in this stauy, since average body condition scores for all examined cows at three periods were not out of the physiological range (Table 3), although data for the percent of liver fat indicated that disturbance of energy metabolisam in cows occures, since $50 \%$ of cows had moderate or severe fatty liver. That was the main reason why we analized body condition of cows in detail. By analyzing body condition losses between different phases of productive-reproductive cycle, as well as the distribution of individual body conditions within different phases of cycles, we tried to estimate the possible relationship between these indicators and fatty liver. According to Kim and Suh (2003) and Šamanc et al. (2008) physiologically accepted loss in body condition between two consecutive phases 
of productive-reproductive cycles (dry period/puerperium and puerperium/month 2 of lactation) is up to 0.7 and up to 1.5 between puerperium and month 2 of lactation. It may be seen from table 4 that as much as $38 \%$ of cows had marked body condition loss between the dry period and puerperium, while $20 \%$ of cows had marked body condition loss between dry period and month 2 of lactation. This indicates that difference in body conditions between different phases of cycles may be used as an additional, ease to use, diagnostic indicator for assessment of energy status of cows.

Interesting conclusions can be made when data for body conditions are presented as distribution of individual values for cows (Figures 1 to 3). Regardless that average body condition scores were within the physiological range, individual values for body condition in the dry period and puerperium were, in a significant percent, out of the physiological range (39 and $49 \%$ respectively).

In our study, we presented data for average BCS, body condition loss and distribution of individual values separately for cows with different fatty liver degree (mild, moderate and severe). Only dry cows with severe fatty liver had body condition score higher than physiologically acceptable. All the other values were within physiological (Table 5).

In cows with severe fatty liver, marked loss in body condition appeared more often then in cows with moderate and mild fatty liver, especially between the dry period and puerperium ( $76.47 \%$ of cows). These results indicate that intensive lipomobilisation starts early around calving, before milk production encasement. It is possible that severe fatty liver develops during the last days of pregnancy (Gerloff et al., 1986). Additionally, results indicate that, besides nutrition and body condition, other risk factors are involved in etiology of fatty liver (Bobe et al., 2004; Šaman et al., 2010).

Analyzing data for distribution of individual body condition scores it can be noticed that only $12 \%$ cows with mild fatty liver were obese during the dry period ("shift to right"), while that percent was 64.71 for dry cows with severe fatty liver (Figures 4 and 6). It can be concluded that in more than half of the cases $(64.71 \%)$ obesity may cause fatty liver. In other cases, other etiological factors may be included (Grummer, 1993; Katoh, 2002; Kapp et al., 1979; Jorristma et al., 2000; Goff and Horst, 1997; Šamanc et al., 2010). At month 2 of lactation distribution of individual values for body condition was very similar between cows with a different degree of fatty liver, indicating that most intensive lipomobilization is close to calving. If lipomobilization is too high it may lead to fatty liver.

In conclusion, average body condition score is a valid indicator of energy status of dairy cows, and should be used in everyday practice due to its simplicity. Besides, body condition loss should be used as an additional diagnostic tool for determining energy status of dairy cows, especially loss between dry period and puerperium, since it may indicate on early lipomobilisation which probably starts before calving (Bobe et al., 2004). Our results indicate that severe fatty liver is associated with obesity in dry cows and mark body condition loss between dry period and puerperium. For valid assessment of energy status of dairy cows, it is strongly recommended to analyze the distribution of individual values for body condition at different phases of the productive-reproductive cycle, since it may 
indicate on percent of cows with body condition scores out of physiological range ("shift to left" and "shift to right"). Finally, our results indicate that there is a strong association between average body condition score and body condition loss on fatty liver degree but that, in some cases, factors other than body condition cause fatty liver. These other risk factors are not yet clearly determinate and should be a subject of further investigations.

\section{ACKNOWLEDGEMENTS:}

This work was supported by Ministry of science and technology, Republic of Serbia, Project Grant No 20016.

Address for correspondence:

Danijela Kirovski, DVM, PhD

Department of Physiology and Biochemistry

Faculty of Veterinary Medicine

University of Belgrade

Bulevar Oslobodjenja 18

11000 Belgrade, Serbia

E-mail: dani@vet.bg.ac.rs

\section{REFERENCES}

1. Acorda J, Yamada H, Ghamsari S, 1995, Comparative evaluation of hydropic degeneration of the liver in dairy cattle through biochemistry, ultrasonography, and digital analysis, Vet Radiol Ultrasound, 36, 322-6.

2. Bauman DE, Currie WB, 1980, Partitioning of nutrients during pregnancy and lactation: a review of mechanisms involving homeostasis and homeorhesis, J Dairy Sci, 63, 1514-29.

3. Bewley JM, Boyce RE, Roberts DJ, Coffey MP, Schutz MM, 2010, Comparasion of two methods of assessing dairy cow body condition score, J Dairy Res, 77, 95-8.

4. Bewley JM, Peacock AM, Lewis O, Boyce RE, Roberts DJ, Coffey MP et al., 2008, Potential for estimation of body condition scores in dairy cattle from digital images, J Dairy Sci, 91, 3439-53.

5. Bobe G, Young JW, Beitz DC, 2004, Invited review: patology, etiology, prevention, and treatment of fatty liver in dairy cows, J Dairy Sci, 87, 3105-24.

6. Drackley JK, 1999, ADSA Foundation Scholar Award: Biology of dairy cows during the transition period: the final frontier? J Dairy Sci, 82, 2259-73.

7. Duffield T, 2000, Subclinical ketosis in lactating dairy cattle, Vet Clin North Am Food Anim Pract, 16, 231-53.

8. Gaal T, 2007, Epidemiology of production diseases in dairy cows - Hungarian and other European experiences, $13^{\text {th }}$ International Conference on Production Diseases in Farm Animals, $29^{\text {th }}$ July to $4^{\text {th }}$ August, Leipzig, Germany.

9. Gerloff $B J, 2000$, Dry cow mamagement for the prevention of ketosis and fatty liver in dairy cows, Vet Clin North Am Food Anim Pract, 16, 283-92.

10. Gerloff BJ, Herdt TH, Emery RS, 1986, Relationship of hepatic lipidosis to health and performance in dairy cattle, J Am Vet Med Assoc, 188, 845-50.

11. Goff JP, Horst RL, 1997, Physiological changes at parturition and their relationship to metabolic disorders, J Dairy Sci, 80, 1260-8.

12. Gröhn Y, Heinonen K, Lindberg LA, 1987, Fat infiltration in the liver of Finnish Ayrshire cows during early lactation, Acta Vet Scand, 28, 143-9.

13. Grummer $R R, 1993$, Etiology of lipid-related metabolic disorders in periparturient dairy cows, $J$ Dairy Sci, 76, 3882-96.

14. Grummer RR, 2008, Nutritional and menagament strategies for prevention of fatty liver in dairy cattle, Vet J, 176, 10-20. 
15. Hady PJ, Domecq JJ, Kaneene JB, 1994, Frequency and precision of body condition scoring in dairy cattle, J Dairy Sci, 77, 1543-7.

16. Herdt TH, 1991, Relationship of fat metabolism to health and performance in dairy cattle, Bovine Pract, 26, 92-5.

17. Jorritsma R, Wensing T, Kruip TA, Vos PL, Noordhuizen JP, 2003, Metabolic changes in early lactation and impaired reproductive performance in dairy cows, Vet Res, 34, 11-26.

18. Jorristma R, Jorritsma H, Schukken YH, Barlett PC, Wensing T, Wentink GH, 2001, Prevalence and indicators of post partum fatty infiltration of the liver in nine commercial dairy herds in the Netherlands, Livest Prod, 68, 53-60.

19. Jorristma R, Jorritsma $H$, Schukken $Y H$, Wentink $G H, 2000$, Relationship between fatty liver and fertility and some periparturient diseases in commercial Dutch dairy herds, Theriogenology, 54 , 1065-74

20. Kapp P, Pethes Gy, Zsiros M, Schuster Z, 1979, Adatok a nagyhozamu tejeloszarvasmarhak zsirmajszindromajak korfejlodesehez, Magyar allatorvosok lapja, 34, 458-68.

21. Katoh N, 2002, Relevance of apolipoproteins in the development of fatty liver and fatty liver-related peripartum diseases in dairy cows, $J$ Vet Med Sci, 64, 293-307.

22. Kim IH, Suh $\mathrm{GH}, 2003$, Effect of amount of body condition loss from the dry to near calving periods on the subsequent body condition change, occurrence of postpartum diseases, metabolic parameters and reproductive performance in Holstein dairy cows, Theriogenology, 60, 144556.

23. Markusfeld O, Galon N, Ezra E, 1997, Body condition score, health, yield and fertility in dairy cows, Vet Rec, 141, 67-72.

24. Mazur A, Bazin S, Rayssiguier Y, 1988, Study of hepatic steatosis at the start of lactation in dairy cows consuming grass silage, Reprod Nutr Dev, 28, 171-2.

25. Morrow DA, 1976, Fat cow syndrome, J Dairy Sci, 59, 1625-9.

26. Morrow DA, Hillman D, Dade AW, Kitchen Y, 1979, Clinical investigation of a dairy herd with the fat cow syndrome, J Am Vet Med Assoc, 174, 161.

27. Reid I, Roberts J, 1982, Fatty liver in dairy cows, Vet Rec, 111, 164-9.

28. Reid IM, 1980, Incidence and severity of fatty liver in dairy cows, Vet Rec, 107, 281-4.

29. Roche JR, Friggens NC, Kay JK, Fisher MW, Stafford KJ, Berry DP, 2009, Invited review: Body condition score and its association with dairy cow productivity, health, and welfare, J Dairy Sci, 92, 5769-801.

30. Rukkwamsuk T, Kruip TA, Wensing T, 1999, Relationship between overfeeding and overconditioning in the dry period and the problems of high producing dairy cows during the postpartum period, Vet $Q, 21,71-7$.

31. Rukkwamsuk T, Wensing T, Geelen MJ, 1998, Effect of overfeeding during the dry period on regulation of adipose tissue metabolism in dairy cows during the periparturient period, $J$ Dairy Sci, 81, 2904-11.

32. Smith TR, Hippern AR, Beitz DC, Young JW, 1997, Metabolic characteristics of induced ketosis in normal and obese dairy cows, J Dairy Sci, 80, 1569-81.

33. Stockdale $C R, 2001$, Body condition at calving and the performance of dairy cows in early lactation under Australian conditions: A review, Aust J Exp Agric, 41, 823-39.

34. Šamanc H, Stojić V, Kirovski D, Jovanović M, Cernescu H, Vujanac I et al., 2008, Uticaj telesne kondicije na učestalost i stepen zamašćenja jetre, Veterinarski glasnik, 62, 3-12.

35. Šamanc H, Stojić V, Kirovski D, Jovanović M, Cernescu H, Vujanac I, 2010, Thyroid hormones concentrations during the mid-dry period: an early indicator of fatty liver in Holstein-Friesian dairy cows, J Thyroid Res, 1, 49-54.

36. Van Straten M, Shpige/ NY, Friger M, 2009, Association among patterns in daily body weight, body condition scoring, and reproductive performance in high-producing dairy cows, J Dairy Sci, 92, 9, 4375 -85. 


\title{
NOVI PRISTUP U OCENI TELESNE KONDICIJE I NJENOM UTICAJU NA ZAMAŠĆENJE JETRE KOD KRAVA HOLŠTAJN RASE
}

\author{
ŠAMANC H, KIROVSKI DANIJELA, JOVANOVIĆ M, VUJANAC I, BOJKOVIĆ-KOVAČEVIĆ \\ SLAVICA, JAKIĆ-DIMIĆ DOBRILA, PRODANOVIĆ R i STAJKOVIĆ SILVANA
}

\section{SADRŽAJ}

Cilj istraživanja u ovom radu je bio da se ispita povezanost telesne kondicije i zamašćenja jetre kod visoko-mlečnih krava. Za ogled je izabrano 100 krava holštajn rase u zasušenju. Telesna kondicija je ocenjena jedanput u zasušenju, puerperijumu i 2. mesecu laktacije prema sistemu Elanco Animal Health Buletin Al 8478. Gubitak u telesnoj kondiciji je označen prekomernim ako je iznosio preko 0,7 poena između dve uzastopne faze ciklusa, odnosno preko 1,5 poena između zasušenja i 2. meseca laktacije. Uzorci jetre su uzeti 12 dana nakon teljenja i ispitani na sadržaj masti. Polovina (50\%) krava je imalo blag $(3,92 \pm 3,33 \%$ masti), $33 \%$ srednji $(19,28 \pm 5,18 \%$ masti), a $17 \%$ krava visok stepen zamašćenja jetre $(36,21 \pm 4,55 \%$ masti). Prosečne OTK krava su iznosile 3,79 $\pm 0,55$ (zasušenje), $3,18 \pm 0,34$ (puerperijum) i 2,90 $\pm 0,29$ (2. mesec laktacije). Prekomeran gubitak u telesnoj kondiciji između zasušenja i puerperijuma je imalo $38 \%$ krava, $20 \%$ između zasušenja i 2. meseca laktacije i $8 \%$ između puerperijuma i 2. meseca laktacije. Telesnu kondiciju izvan fizioloških granica je imalo 39\% krava u zasušenju, $49 \%$ krava u puerperijumu i $9 \%$ krava u 2. mesecu laktacije.

Kada su krave podeljene na osnovu stepena zamašćenja jetre, utvrđeno je da su samo krave sa visokim stepenom zamašćenja jetre bile pregojene u zasušenju, kao i da je kod ove grupe krava u 76,47\% slučajeva nastao prekomeran gubitak u telesnoj kondiciji od zasušenja do puerperijuma, u 47,06\% od zasušenja do 2 . od meseca laktacije i u $23,53 \%$ od puerperijuma do 2 . meseca laktacije što ukazuje da pojačana lipomobilizacija kod ove grupe krava počinje u periodu oko teljenja vrlo rano, pre nego što nastane značajan porast u proizvodnji mleka.

Naši rezultati ukazuju na postojanje značajne povezanosti telesne kodnicije i zamašćenja jetre koja se može utvrditi jedino detaljnom analizom telesne kondicije krava u zapatu. Pored toga, rezultati jasno ukazuju da telesna kondicija nije jedini etiološki faktor u nastanku masne jetre kod krava. 